\title{
SEEDBANK AND SEEDLING EMERGENCE CHARACTERISTICS OF WEEDS IN RICEFIELD SOILS OF THE MUDA GRANARY AREA IN NORTH-WEST PENINSULAR MALAYSIA
}

\author{
MAHFUZA BEGUM"*, ABDUL SHUKOR JURAIMI", SYED OMAR BIN SYED RASTAN", RAJAN AMARTALINGAM^ AND AZMI BIN \\ MAN $^{2)}$ \\ " Faculty of Agriculture, University Putra Malaysia, 43400 Sci'dang. Malaysia l, Pulau Pinang, Malaysia
}

\begin{abstract}
Tlie experiment was conducted in the glasshouse of UPM from March 2003 to June 2004 to determine the soil seedbank in the ricefields ot'Muda rice granary area in Peninsular Malaysia. Six soil cores of $5 \mathrm{~cm}$ in diameter and $10 \mathrm{~cm}$ depth were sampled from each of 24 fields. All samples from each individual field were bulked and placed in plastic trays of $38 \times 25 \times 10 \mathrm{~cm}$. Soil was moistened as required and emergence of weed seedlings were recorded over period of one year. After one year, remaining seeds were separated, removed and identified. The total seed bank was estimated at 1136.48 million/ha of which $62.35 \%$ (708.60 million seedlings ha"1) germinated within 12 months and $37.65 \%$ (427.88 million seeds ha" ${ }^{11}$ ) remained ungerminated. Total of 20 taxa were recognized. Based on importance value (I.V.) the five most dominant species in terms of emerged seedling were Fimbristylis miliacea, Leplochloa chinensis, LitJwigia hyssopifolia, Cyperus difformii and C. iria. Of the remaining seeds the five dominant species with decreasing trend in ranking were F. miliacea, Scirpus lateriflonis, Monochoria vagina/is, L. hyssopifolia and L. chinensis. Ranking of total seed reserves (seedlings+ remaining seeds) were similar to emerged seedling indicating that emerged seedlings reflect the actual weed flora in the Muda area. Among the dominant species F. miliacea accounted for $58.07 \%$ of emerged seedlings, $79.31 \%$ of remaining seeds and $66.07 \%$ of total seed bank. Total seedling emergence of all species was higher in the first observation in April 2003 and cumulative seedling emergence showed no clear peaks.
\end{abstract}

Key words : Seedbank, seedling emergence, weeds, ricefield soils, Malaysia

\section{INTRODUCTION}

The weed seedbank comprising viable seeds either on the surface or in the soil, is the principal source of annual weed infestations in field crops. The seedbank consists of new seeds recently shed by weeds and older seeds that have persisted in the soil for several years. Changes in agricultural management practices alter the pattern of disturbance and produce changes in seedbank characteristics. Changes in these seedbank characteristics often lead to changes in the size and species composition of the weed flora (Roberts and Neilson 1981; Wrucke and Arnold 1985; Cardinal/. 1991; Clementsetal. 1996).

\footnotetext{
*Corresponding author: mafupaz@hotmail.com
} 
In Muda rice granary, the change in cultural practices and use of agrochemicals had led to a shift in species from broad-leaved sedge dominance weed flora to grasses (Azmi et al. 1995). The building up of certain weed species with continuous use of particular herbicides may be due to inherent resistance to that herbicide or the continuous absorption of the herbicide at sub-lethal concentrations leading to gradual development of herbicide resistance. Sometimes, elimination of the competitors of a particular weed favours the abundance and predominance of the weed in that particular environment (Azmi and Baki 1995; Ho 1998). These weeds produce abundant viable seeds and generally the vast majority of seeds entering the seedbank come from such annual weeds growing on the land (Roberts 1981; Hume and Archibold 1986), and would thus represent the potential weed flora (Kott 1947; Rahman et al. 1995). Therefore, knowledge of the dynamics of the seedbank is necessary to determine whether weed seed population has changed and the rate of change.

Species composition of the flora may be sometimes more important than total number of seeds (Roberts and Ricketts 1979). However, weed seed populations in cultivated soils are generally composed of a few dominant species that are present in high numbers, a few others present at moderate levels, and a large variety of species present in the soil at low levels (Vengris 1953; Wilson and Furrer 1996). Knowledge of the size and species composition of this seedbank would be useful in predicting future weed infestations (Carretero 1977).

The fate of seeds in the soil is difficult to determine and comprehensive information on the seed pool dynamics of most species is sparse. High weed seed populations occur in tropical soils, but limited data is available on emergence patterns (Zimdahl et al. 1988). Most weeds show some periodicity of emergence (Roberts and Margaret 1980). Practical knowledge of periodicity of germination is of significant importance, since it is a major factor in determining the association of weeds with cropping systems and to enable a degree of forecasting as to which weed species may occur in a seedbed. Predicting potential weed emergence is fundamental in the development of integrated pest management strategies for weed control. Predictions of emerged seedling densities allow estimations of weed competition, crop yield loss, need for herbicides, financial returns and weed seed production at the end of the growing season (Forcella 1992). Furthermore, the remaining seeds in the soil are also a major concern to understand the soil seedbank status (Cardina and Sparrow 1996).

This study was conducted to determine the germinable seedbank, total seed reserve, species composition of the entire germinable seedbank, ranking of species and their emergence pattern in the soils of the Muda rice granary area.

\section{MATERIALS AND METHODS}

Sample sites were located in northern parts of Muda ricefields at Kedah in the north-west of Peninsular Malaysia. Soil samples were obtained from 24 fields in March 2003. Six soil cores of $5 \mathrm{~cm}$ in diameter and $10 \mathrm{~cm}$ depth were sampled from 
each field in a W shaped pattern. Samples from each individual field were bulked and air-dried in the glasshouse. Subsequently, the soil samples were passed through a 4-mm sieve to remove large debris and break up soil pods. Samples from each of the 24 fields were placed in $38 \times 25 \times 10$ $\mathrm{cm}$ plastic trays. Each plastic tray was filled with $2.0 \mathrm{~kg}$ of soil. The samples were daily sprinkled with water as needed in order to keep them moist.

Weed seedlings that emerged were identified, counted, and removed at one-month intervals, throughout the one-year germination period. Seedlings were identified using the seedling keys of Chancellor (1966). Weedy rice seedlings were excluded in this study because of the obvious difficulty of identifying between weedy rice and off-type rice. Seedlings of questionable identity were transferred to pots and grown until maturity to facilitate identification. After the removal of each batch of seedlings, soils were air dried for 3 days, thoroughly mixed in order to expose the weed seeds to the upper layer of the soil, and rewetted to permit further germination. This process was repeated 12 times from March 2003 to February 2004.

After one year any remaining seeds were separated by the method described by Wilson et al. (1985). The soil in each tray was passed through a descending series of five sieves containing screens of the following sizes: $4 \mathrm{~mm}$ (5 mesh), $2 \mathrm{~mm}$ (10 mesh), 850 jim (20 mesh), 425 urn (40 mesh), and 250 urn (60 mesh). Water was run through the sieves to enhance sample separation through the screens. The contents collected in each screen were removed, sun dried, and seeds were removed under a luminated magnifier. Seeds from entire samples were sorted using a dissecting microscope and counted according to species. The seed counts were expressed in numbers per $\mathrm{m}^{2}$. The total of emerged seedling during one year period and the remaining seeds represent the total species composition and seed reserve of respective species. Seed and seedling counts were converted to numbers per $\mathrm{m}^{2}$ within $10 \mathrm{~cm}$ soil depth.

The Importance Value (I.V.) was expressed based on the equation:

Number of each species in a community

$$
\text { I.V. }(\%)=\frac{\text { Total number of all species in a community }}{100}
$$

\section{RESULTS AND DISCUSSION Seedbank density}

Total seed reserve in the Muda area was 113648 seeds $\mathrm{m}^{\text {"2 }}$ equivalent to 1136.48 million ha"1 , of which 70860 seeds m"12 germinated within 12 months and remaining seeds were $42788 \mathrm{~m}^{\prime 2}$ (Table 1). The total number of buried seeds as well as germinable seeds reported here are higher compared with 29551 viable seeds $\mathrm{m}^{\prime 2}$ reported by Pane (1997) and much lower than densities of 712228 to 930910 
seeds $\mathrm{m}^{\prime 2}$ recorded by Ismail et al. (1995) in direct-seeded ricefields at Kampung Tandop in Muda area. However, Watanabe et al. (1997) noted that such abundance reported by the latter tar exceeds that usually observed in cropped land, including upland ricefields' which had two orders of magnitude lower. While in the Philippines, Vega and Sierra (1970) reported more or less similar viable seeds as the present study, with 800 million seeds ha"' in ricefields within a plough depth of about $15 \mathrm{~cm}$.

\section{Species composition in seedbank}

A total of 20 taxa were recognized, of which 14 common weed species emerged from the soils collected in the Muda area (Table 1). Based on dominance ranking, the highest population of seedlings that emerged were of $F$. miliacea followed by $L$. chinensis, $C$. difformis, C. iria, L. hyssopifolia, Sphenoclea zeylanica, M. vaginalis, Limnophila erecta, Hedyotis diffusa, Ceratopteris thalictroides, Echinochloa crus-galli (complex), Bacopa rotundifolia and Eleocharis variegata and E. colona (Table 1). Pane (1997) reported 17 species in Muda ricefields of which the higher population of seedlings emergence were L. chinensis, F. miliacea, C. difformis, S. zeylanica, L. octovulvis, M. vaginalis, C. iria, Lindernia octovulvis, E. crus-galli, and Sagittaria guyanensis. The dominant species were almost similar as in the present study. Another seven species were rare and present in relatively low numbers.

After the 12-month gennination period, the seeds remaining in soils comprised 13 weed species (Table 1 ). Of these weed species seven, namely F. miliacea, $L$. chinensis, C. difformis, C. iria, L. hyssopifolia, M. vaginalis and E. crus-galli (complex) had been recorded as seedlings during the 12- month period, while seeds of 6 weed species, previously not found as seedlings, were from Scirpus lateriflorus, $S$. juncoides, S. guyanensis, Nymphoides indica, Najas graminea and Cleome viscosa. The non-emergence of these species may be due to the very low population of these species combined with low germination rate. Ismail et al. (1995) had observed that although seeds of $S$. juncoides were the dominant species in volunteer seedling fields in the Muda area, but its summed dominance ratio values of emerging seedlings was very small, which also indicate its low germination rate.

Seeds of S. lateriflorus, S. juncoides, S. guyanensis can persist in the dormant state in the soil and dormancy may be broken through straw burn and tillage (Azmi 2005; pers. Comm.). No remaining seeds were detected for seven weed species which had germinated during 12 months period, namely $S$. zeylanica, C. thalictroides, L. erecta, $H$. diffusa, E. variegata, B. rotundifolia and E. colona (Table 1). Ismail et al. (1995) also observed that although $C$. thalictroides, Hedyotis sp., Bacopa sp. emerged in direct seeded ricefields in Muda, no seeds of these species was found in soil seed reserves. Based on total seed reserve, the species composition in descending order was $F$. miliacea, L. chinensis, L. hyssopifolia, C. difformis, C. iria, M. vaginalis, S. zeylanica, S. lateriflorus, L. erecta, E. crus-galli (complex), C. thalictroides, H. diffusa, S. juncoides, S. guyanensis, B. rotundifolia, N. indica, E. variegata, N. graminea, E. colona and C. viscosa (Table 1). However, 
Seeclbank and seedling emergence characteristic of weeds - M. Begum el al.

Table 1. Germinable soil seedbank, remaining seed and total seed reserves in the Muda rice granary area

\begin{tabular}{|c|c|c|c|}
\hline Weed species & $\begin{array}{l}\text { Seedbank germinable } \\
\text { within } 12 \text { months } \\
\text { (no.m"2) }\end{array}$ & $\begin{array}{l}\text { Remaining seed } \\
\text { reserves (no.m"1"2) }\end{array}$ & $\begin{array}{l}\text { Total seed reserve } \\
\text { (germinable seeds + } \\
\text { remaining seeds) }\end{array}$ \\
\hline F. miliacea & 41148 & 33936 & 75084 \\
\hline L. chiiienxis & 7655 & 989 & 8644 \\
\hline C. difformis & 4947 & 42 & 4989 \\
\hline C. iria & 4530 & 428 & 4958 \\
\hline L. hyssopifolia & 3633 & 1561 & 5194 \\
\hline S. zeylanica & 2402 & - & 2402 \\
\hline M. vaginali.i & 1481 & 1598 & 3079 \\
\hline L. erecta & 1292 & - & 1292 \\
\hline H. diffusa & 1129 & - & 1129 \\
\hline C. thalictroides & 1045 & - & 1045 \\
\hline E. crus-galli & 670 & 477 & 1147 \\
\hline B. mtundifolia & 644 & ' & 644 \\
\hline E. variegata & 227 & - & 227 \\
\hline E. colona & 57 & - & 57 \\
\hline S. laterifloms & - & 1613 & 1613 \\
\hline S.juncoides & - & 943 & 943 \\
\hline S. guyanensis & - & 742 & 742 \\
\hline$N$. indica & - & 235 & 235 \\
\hline N. gramineu & - & 201 & 201 \\
\hline C. viscosa & - & 23 & 23 \\
\hline Total & 70860 & 42788 & 113648 \\
\hline
\end{tabular}

due to the limited size of soil samples analyzed for seeds, only seeds of most predominant species were expected to be detected with consistency (Forcella et al. 1992).

\section{Occurrence of species frequency}

The frequency of occurrence of emerged seedlings and remaining seeds of individual component species in the seedbank are shown in Table 2. F. miliacea, L. chinensis and $L$. hyssopifolia were most frequent, and found in all sampled fields (100\% frequency), followed by C. difformis (95.83\%), C. iria (95.83\%), M. vaginalis (95.83\%), S. zeylanica (91.67\%), E. crus-galli (91.67\%), L. erecta (83.33\%), C. thalictroides (75\%) and H. diffusa (58.33\%) (Table 2). These were found in large numbers up to $1046-41148$ in"'2, except E. crus-galli, which had a high frequency of occurrence but the number of seeds was $670 \mathrm{~m}^{\prime 2}$ (Table 2). Watanabe et al. (1997) observed that Echinochloa species were well controlled by herbicide and few adult plants, less than eight plants $\mathrm{m}^{\prime 2}$ (mostly 0-3 plants $\mathrm{m}^{\prime 2}$ ) were observed growing after rice heading. Average number of spikelets/plant of E. crus-galli was 972 (Watanabe et al. 1997) which was lower than other dominant species 
(viz. L. chinensis, 1877 spikelets per plant). In spite of the frequency, total seed incorporation was lower than with other dominant species like $L$. chinensis, $F$, miliacea, $L$. hyssopifolia, $C$. iria, C. difformis etc. In the case of remaining seeds, the most frequent species were $M$. vaginalis (87.5\%), F. miliacea (83.33\%), L. hyssopifolia (83.33\%), 5. giiyanensis (79.19\%), S. lateriflorus (70.83\%), E. crus-galli (complex) (58.33\%) and L chinensis (54.17\%).

All species had large seed populations, except E. cms-galli (complex). Bahtia et al. (1990) reported that seed reserves of E. crus-galli were mostly $97.7 \%$ exhausted during one season and only a small fraction (2.3\%) carried over to the second season. No seed germination occurred during the third season and soil was free of viable seeds. Similarly, Azmi et al (1995) detected very few viable seeds of Echinochloa crus-galli in the soil after six cropping seasons, suggesting seed longevity of barnyard grass in ricefields was shorter than three years.

This study revealed that most frequent species appeared as a most dominant species. The percentage of occurrence of many species were high which have higher percentage viability than $M$ vaginalis and F. miliacea (Table 2). This indicates that these species are persistent in the seed bank, and hence become dominant in the above ground flora, even though there was a shift towards grassy weeds due to changes in the cultural practice from transplanting to direct seeding.

\section{Dominant species in seedbank}

According to importance value, the five most dominant species in terms of emerged seedlings were F. miliacea (58.07\%), L. chinensis (10.80\%), C. difformis (6.98\%), C. iria (6.39\%) and L. hyssopifolia (5.13\%) with another eight weed species sharing only $12.55 \%$ of the total emerged seedlings (Figure la). In terms of seeds remaining in the soil after 12 months, the five most important species were F. miliacea (79.31\%), S. laterifloms (3.77\%), M. vaginalis (3.74 \%), L. hyssopifolia (3.65\%) and L. chinensis (2.31\%), while other species shared only $7.22 \%$ (Figure Ib). The five most dominant weed species in terms of total seed reserves (seedling + remaining seeds) in the Muda area were F. miliacea $(66.07 \%)$, L. chinensis (7.61\%), L. hyssopifolia (4.57\%), C. difformis (4.39\%) and C. iria (4.36\%) while the rest of the species shared only $13 \%$ of the total seed reserve (Figure Ic). This was similar to the germinable seedlings of 12 months period, but with slight variation in ranking of species. Pane (1997) reported that the predominant weed species in the Muda area, with respect to emerged seedlings in the seedbank study, were $L$. chinensis, F. miliacea, C. difformis. S. zeylanica and $L$. octovulvis. The results were almost similar to the present study, but the relative percentage and ranking were slightly different. Reserves of seeds in soil are typically dominated by two to four species (Wilson and Furrer 1996). At IRRI, Zimdahl et al. (1988) reported that in lowland irrigated ricefields three weed species, namely C. difformis (52\%), F. miliacea (26\%) and M. vaginalis (18\%) , covered $96 \%$ of total emerged seedlings.

In this study emergence density, ungerminated seeds and total seed reserve of F. miliacea were much higher than other weeds. Watanabe et al. (1996) also observed 
Seedbank and seedling emergence characteristic of weeds - M. Begum et al.

Table 2. Frequency of occurrence and viability of individual weed species in the soil seedbank

\begin{tabular}{lcclc}
\hline Weed species & $\begin{array}{c}\text { Frequency of } \\
\text { emergence } \\
\text { seedling (\%) }\end{array}$ & $\begin{array}{c}\text { \% viability (12 } \\
\text { months period) }\end{array}$ & Weed species & $\begin{array}{c}\text { Frequency of } \\
\text { occurrence of } \\
\text { remaining seeds } \\
(\%)\end{array}$ \\
\hline F. miliacea & 100.00 & 54.80 & M. vaginalis & 87.50 \\
L. chinensis & 100.00 & 88.56 & F. miliacea & 83.33 \\
L. hyssopifolia & 100.00 & 69.95 & L. hyssopifolia & 83.33 \\
C. difformis & 95.83 & 99.16 & S. guyanensis & 79.19 \\
C. iria & 95.83 & 91.37 & S. lateriflortis & 70.83 \\
M. vaginalis & 95.83 & 48.13 & S. juncoides & 62.50 \\
S. zeylanica & 91.67 & 100.00 & E. crus-galli & 58.33 \\
E. crus-galli & 91.67 & 60.37 & L. chinensis & 54.17 \\
L. erecta & 83.33 & 100.00 & C. iria & 50.00 \\
C. thalictroides & 75.00 & 100.00 & N. graminea & 41.67 \\
H. diffusa & 58.33 & 100.00 & N. indica & 29.17 \\
B. rotundifolia & 54.17 & 100.00 & C. difformis & 20.83 \\
E. variegata & 20.83 & 100.00 & C. viscosa & 20.83 \\
E. colona & 25.00 & 100.00 & & \\
\hline
\end{tabular}

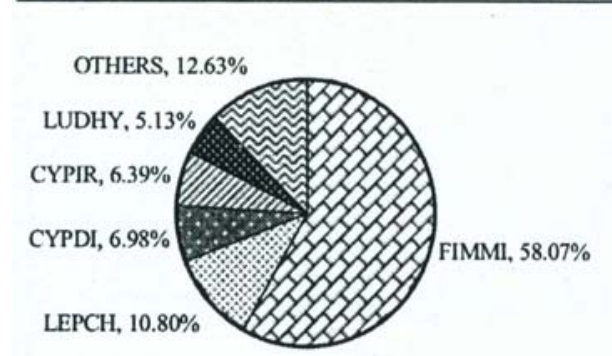

( a )

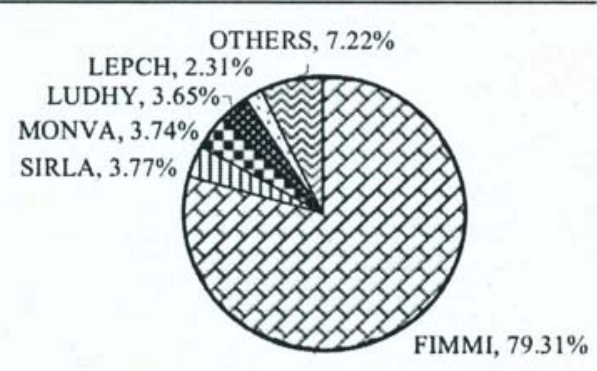

( b )

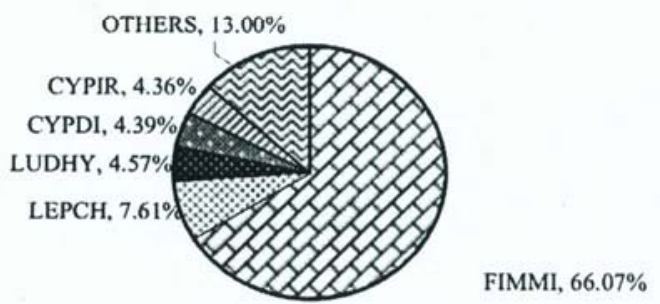

(c)

Figure 1. Relative proportion of germinable seeds (a), ungerminated seeds (b), and relative proportion of total soil seedbank (c) of five most important weed species in the soil seedbank in Muda ricefields

Note : FIMMI- F. miliacea; LEPCH- L chinensis; CYPDI- C. difformis; CYPIR- C. iria and LUDHY- L. hyssopifolia; MONVA- M. vaginalis; SIRLA- $S^{1}$. lateriflorus. 
higher emergence of F. miliacea seedlings in the Muda area. Pane (1997) reported a F. miliacea germinable seedbank of $22.9 \%$, which was lower than this study, but was the second most dominant species after $L$. chinensis (26.9\%), which according to Ho et al. (1995) occupied $80 \%$ of above-ground weed flora. The domination of the seedbank by a single annual species, in this case F. miliacea, is not unusual. A single species often comprises over half of the soil seedbank (Thompson 1986; Schott and Hamberg 1997; Navie et al. 2004). Common lambsquarters comprised more than $50 \%$ of the seedbank (Clements et al. 1996). These clearly explain the huge seedbank and persistence o'f $F$. miliacea in the area.

\section{Emergence pattern}

In general, weed emergence is influenced by soil disturbance, temperature, rainfall, soil moisture and radiant energy. In the present study the highest percentage of emerged seedlings was recorded in the first observation in April (20.29\%). Seedlings emerged with each soil disturbance at emergence rates of between 4.45-20.29. Seedlings continued to emerge irrespective of the time of year, but in reduced numbers. However, periodic seedling emergence showed no clear peaks during the 12-month period (Figure 2). Within the first two months $32.84 \%$ of seedlings had emerged and more than $50 \%$ seedlings emerged within 5 months.

Watanabe et al. (1996) observed that weed seedlings emerged mostly in the first thirty to forty days after rice seeding, although L. chinensis, F. miliacea, M. vaginalis, L. hyssopifolia, and broadleaved weeds often emerged over a longer duration. Zimdahl et al. (1988) observed that one third of all weed species emerged within 3 weeks of tillage, and 57\% emerged within 6 weeks in upland soils at IRRI, whereas 38 and 51\% of total emergence occurred within 3 and 6 weeks after tillage, respectively. Jensen (1969) also found seedling emergence accounted for

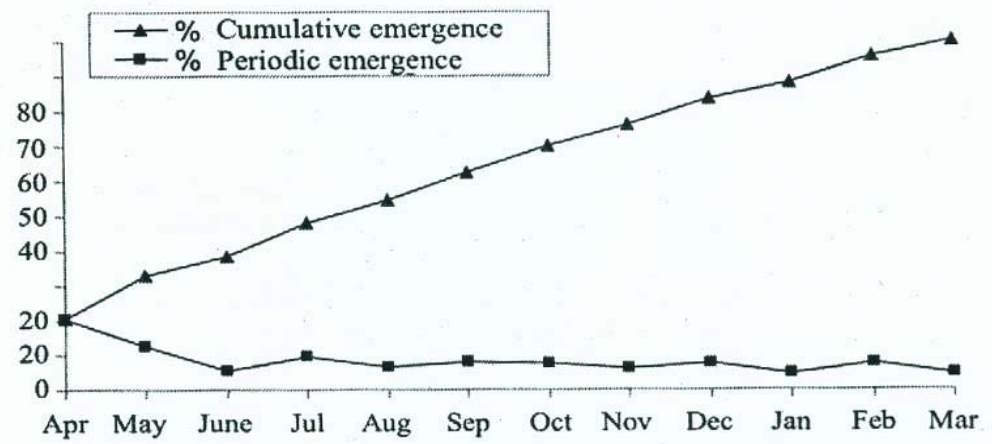

Figure 2. Periodic and cumulative total weed seedling emergence in Muda ricefields soils during the 12-month period 
only about $25 \%$ of the seeds in the soil and that most of those that did so in the first month. He found the strong correlation between immediate seedling emergence in the glasshouse and field emergence suggests only the first flush of seedling emergence need to be considered.

\section{CONCLUSIONS}

A total 20 taxa (including seedling + remaining seeds) were found of which 14 species were germinable, while six species did not germinate during the 12-month period in this study. Total seed reserve was 1136.48 million ha"' of which 708.60 million ha'" was germinable within the 12month period. Previous studies had only reported the germinable seedbank in sampled soils. No information was available on dormant seeds of different species, which would reflect the actual seed reserves of the Muda area. F. miliacea, L. chinensis, L. hyssopifolia, C. difformis and C. iria appeared to be the most frequent species and made up the bulk of the seed population in the soil, with more than $80 \%$ occurring as a germinable seedbank. Among these important species the domination of the seedbank by a $F$. miliacea comprised $58.07 \%, 79.31 \%$ and $66.07 \%$ of germinable seedbank, ungerminated seeds and total seed reserves, respectively. The result indicates that the very large size of this seedbank is probably due to both its prolific seed production and the ability of its seeds to persist more than a year.

It would be valuable to predict the size of a weed infestation before it actually occurred, and this is especially true if reliance is to be placed on pre-emergence herbicides, which must be applied before the nature and severity of the potential infestation are visible. To determine whether site-specific weed management is practical, the first criterion is to decide whether weeds (density, species) vary enough from field to field. The second step is to obtain accurate and reliable information about weed species and density on specific field. The third step matches weed management solutions with problems.

\section{ACKNOWLEDGEMENT}

Our appreciation goes to the Third World Organization for Women in Science (TWOWS) Trieste, Italy and Universiti Putra Malaysia under the Intensification of Research in Priority Areas (IRPA) (No.: 01-02-04-0778-PR0068/05-05 ) who had provided the grant of postgraduate fellowship and research facilities for this study.

\section{REFERENCES}

Azmi, M. and B.B. Bald. 1995. The succession of noxious weeds in tropical Asian ricefields with emphasis on Malaysian rice ecosystem. In: Proceeding 15* Asian Pacific Weed Science Society Conference, Tsukuba, Japan, p. 51-67.

Azmi, M., M. Mashhor, K. Itoh, and H. Watanabe. 1995. Life cycle and seed longevity of Echinochloa crus-galli complex in direct seeded rice in Malaysia. In: Proceeding of 15 Asian Pacific Weed Science Conference, Tsukuba, Japan, p. 505-511. 
Bhatia R.K., K..S. Sandhu and T. Singh. 1990. Geiinination and longevity of Echinochloa crus-galli L. under natural conditions. J. Res. Punjab Agric. Univ., 27 (1):17-21.

Carretero, /.L. 1977. Estimation del contenido de semillas de malas hierbas de un suelo agricola como prediction de su flora adventicia. Ann. Inst. Biol. Caranilles, 34: 267-278.

Cardina, J., E. Regnier and K. Harrison. 1991. Long-term tillage effects on seedbanks in three Ohio soils. Weed Sci., 39: 186194.

Cardina, J. and D.H. Sparrow. 1996. A comparison of methods to predict weed seedling populations from the soil seedbank. Weed Sci., 44: 46-5 1.

Chancellor, R.J. 1966. The identification of weed seedlings of farm and garden. Blackwell Scientific Publication, Oxford.

Clements, D.R., D.L. Benoit, S.D. Murphy and C.J. Swanton. 1996. Tillage effects on weed seed return and seedbank composition. Weed Sci., 44:3 14-322.

Forcella, F. 1992. Prediction of weed seedling densities from buried seed reserves. Weed Res., 32: 29-38.

Forcella, F., R.G. Wilson, K..A. Renner, J. Dekker, R.G. Harvey, D.A. Aim, D.D. Buhler and J. Cardina. 1992. Weed seedbanks of the U.S. cornbelt: Magnitude, variation, emergence and application. Weed Sci., 40: 636-644.

Jensen, H.A., 1969. Content of buried seeds in arable soils in Denmark and its relation to the weed population. Dansk Botanisk Arkiv., 27: 7-57.

Ho, N.K. 1998. The rice agro-ecosystem of the Muda Irrigation Scheme: An Overview. In: Nashriah et at. (eds.) Rice Agrosystem of the Muda Irrigation Scheme, Malaysia. Malaysian Institute of Nuclear Technology Research (MINT) and MADA, Bangi, Kajang, Malaysia, p. 1-24.

Ho, N.K., Y.M. Esa, and M. Abu Bakar. 1995. Implementation of agricultural extension programme on integrated weed management in rice: Malaysia approaches and experience. Rice 1PM Network Workshop on Weed Management in Rice Production. 19-23 June 1993. Ferringhi Beach Hotel, Penang, Malaysia, p. 14.

Hume, L. and O.W. Archibold. 1986. The influence of a weedy habitat on the seed bank of an adjacent cultivated field. Canadian J. of Bot., 64: 1879-1883.

Ismail, S., Z.N. Faezah and N.K. Ho. 1995. Weed population and their buried seeds in ricefields of the Muda area, Kedah, Malaysia. Pertanika J. Trop. Agric. Sci., $18(1): 21$-28.

Kott, S.A. 1947. The biological properties of weedy plants and the struggle against the wecdiness of soils. Ogiz-Sel Khozgiz. Moskva.

Navie, S.C., F.D. Panetta, R.E. McFadyen, and S.W. Adkins, 2004. Germinable soil seedbanks of central Queensland rangelands invaded by the exotic weed Parthenium hysterophoru.i L. Weed Biol. and Manag.,4: 154-167.

Pane, H., 1997. Studies on ecology and biology of red sprangletop [ LeptocMoa chinensis) (L.) Nees] and its management in direct seeded rice. Ph. D. Thesis. Universiti Sains Malaysia, pp. 41-60.

Rahman, A., T.K. James, N. Grbavac, and J. Mellsop. 1995. Evaluation of two methods for enumerating the soil weed seedbank. In Proceedings $4 S^{1 \prime}$ N.Z Plant Protection Conference, www.hortnet.co.nz /

Roberts, H.A. and M.E. Ricketts. 1979. Quantitative relationships between the weed flora after cultivation and the seed population in the soil. Weed Res., 19:269-275.

Roberts, H.A. and E. Margaret. 1980. Emergence patterns of weed seedlings in relation to cultivation and rainfall. Weed Res., 20:377-386. 
Roberts, H.A. 1981. Seed banks in soils. Advances Appl. Biol., 6:1-55.

Roberts, H.A. and J.E. Neilson. 1981. Changes in the soil seedbank of four long-term crop/herbicide experiments, i. Appl. Ecol., 18: 661-668.

Schott, G.W. and S.P. Hamberg. 1997. The seed rain and seedbank of an adjacent native tallgrass prairie and old field. Can. J. Bot., 75:1-7.

Thompson, K. 1986. Small-scale heterogeneity in the seedbank of an acidic grassland. J. Ecol., 74 : 733-738.

Vega, M.R. and J.N. Sierra. 1970. Population of weed seeds in a lowland rice field. Phillipp. Agric., 54:1-7.

Vengris, J. 1953. Weed populations as related to certain cultivated crops in the Connecticut River Vally, MA. Weeds, 2: 125134.

Watanabe, H., M. Azmi, and Md. Z. Israail. 1997. Emergence of major weeds and their population change in wetseeded rice fields of the Muda area, Peninsular Malaysia. In: Proceedings of 16th Asian Pacific Weed Science Society Conference, Malaysian Plant Protection Society, Rajan, A. (ed.), Kuala Lumpur, pp. 246-250.

Wilson, R.G., E.D. Derr and L.A. Nelson. 1985. Potential for using weed seed content in the soil to predict future weed problems. Weed Sci., 33:171-175.

Wilson, R.G. and J. Furrer. 1996. 1996. Where do weeds come from? University of Nebraska-Lincoln Cooperative Extension, http : // www.iam-.unl.edu/pubs /weeds / g807.htm

Wrucke, M.A. and W.E. Arnold. 1985. Weed species distribution as influenced by tillage and herbicides. Weed Sci., 33; 853856.

Zimdahl, R.L., K.. Moody and R.T. Lubigan. 1988. Patterns of weed emergence in tropical soil. Weed Sci., 36: 603-608. 